\title{
Exploring the Celtic Narrative in Advertising: Goddess Culture and the Lexicon of Perfumery
}

Stevens, L. M. R., \& Maclaran, P. (2007). Exploring the Celtic Narrative in Advertising: Goddess Culture and the Lexicon of Perfumery. Journal of Strategic Marketing, 15(1), 29-39. https://doi.org/10.1080/09652540701525948

Link to publication record in Ulster University Research Portal

\section{Published in:}

Journal of Strategic Marketing

Publication Status:

Published (in print/issue): 01/02/2007

DOI:

10.1080/09652540701525948

\section{Document Version}

Publisher's PDF, also known as Version of record

\section{General rights}

Copyright for the publications made accessible via Ulster University's Research Portal is retained by the author(s) and / or other copyright owners and it is a condition of accessing these publications that users recognise and abide by the legal requirements associated with these rights.

\section{Take down policy}

The Research Portal is Ulster University's institutional repository that provides access to Ulster's research outputs. Every effort has been made to ensure that content in the Research Portal does not infringe any person's rights, or applicable UK laws. If you discover content in the Research Portal that you believe breaches copyright or violates any law, please contact pure-support@ulster.ac.uk. 
This article was downloaded by: [University of Ulster at Coleraine]

On: 10 August 2012, At: 09:01

Publisher: Routledge

Informa Ltd Registered in England and Wales Registered Number: 1072954 Registered

office: Mortimer House, 37-41 Mortimer Street, London W1T 3J H, UK

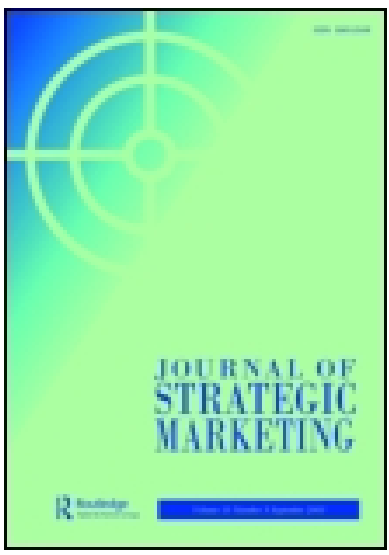

\title{
J ournal of Strategic Marketing
}

Publication details, including instructions for authors and subscription information:

http:// www.tandfonline.com/loi/ rjsm20

\section{Exploring the Celtic narrative in advertising: goddess culture and the lexicon of perfumery}

\author{
Lorna Stevens ${ }^{a} \&$ Pauline Maclaran ${ }^{b}$ \\ a School of International Business, University of Ulster, Magee \\ Campus, Londonderry, BT48 7J L \\ ${ }^{b}$ School of Economics \& Management Studies, Keele University, \\ Keele, Staffordshire, ST5 5BG \\ Version of record first published: 28 Feb 2007
}

To cite this article: Lorna Stevens \& Pauline Maclaran (2007): Exploring the Celtic narrative in advertising: goddess culture and the lexicon of perfumery, J ournal of Strategic Marketing, 15: 1, 29-39

To link to this article: http:// dx. doi.org/ 10.1080/09652540601129973

\section{PLEASE SCROLL DOWN FOR ARTICLE}

Full terms and conditions of use: http://www.tandfonline.com/page/terms-andconditions

This article may be used for research, teaching, and private study purposes. Any substantial or systematic reproduction, redistribution, reselling, loan, sub-licensing, systematic supply, or distribution in any form to anyone is expressly forbidden.

The publisher does not give any warranty express or implied or make any representation that the contents will be complete or accurate or up to date. The accuracy of any instructions, formulae, and drug doses should be independently verified with primary sources. The publisher shall not be liable for any loss, actions, claims, proceedings, demand, or costs or damages whatsoever or howsoever caused arising directly or indirectly in connection with or arising out of the use of this material. 


\section{Exploring the Celtic narrative in advertising: goddess culture and the lexicon of perfumery}

\section{LORNA STEVENS*}

School of International Business, University of Ulster, Magee Campus, Londonderry, BT48 7JL

\section{PAULINE MACLARAN}

School of Economics \& Management Studies, Keele University, Chancellor's Building, Keele, Staffordshire, ST5 5BG

Legendary Brands forge deep bonds with consumers through narrative devices. They are storytellers, drawing from a library of timeless narratives and myths to captivate consumers and sustain meaning across cultural borders. It is the narrative of the Legendary Brand that generates and sustains consumer affinity. (Vincent, 2002)

\section{INTRODUCTION}

Marketing often draws on mythology in order to give products heroic properties and thus communicate with consumers in compelling ways. This often includes the use of archetypal images and themes in the form of cultural myths that resonate with us in powerful and often unconscious ways (Hirschman, 2000). With complex narrative structures that communicate at a deep emotional level, mythic representations are continually being created and recreated, presented and re-presented in the marketplace (Thompson, 2004). Myths help us resolve cultural contradictions and understanding their role is particularly important for marketers, given that many brands now compete in 'myth markets', rather than product markets (Holt, 2004, p. 39).

In this article we identify and analyse the mythic content of a strand of advertising that presents archetypes of contemporary womanhood. We show how these images embody archetypes that are drawn from our pre-modern, Celtic past and how they resolve some of the tensions inherent in the dichotomous thinking that equates women with nature and the body, in binary opposition to men's equation with culture and the mind (Paglia, 1992). We suggest how Celtic archetypes of womanhood are derived from ancient beliefs in a goddess culture. Of particular interest to us is women's association with nature and supernatural forces, a pagan concept embraced by our Celtic ancestors, and one that can be traced to ancient, pre-Christian times, to a period when humanity worshipped a mother goddess. We will argue that Celtic culture, and Christianity that followed it, borrowed many values from this earlier, primordial past.

\footnotetext{
* Corresponding author: lmr.stevens@ulster.ac.uk
} 
We will focus our discussion on the perfume industry, which from time immemorial has sought to define and capture the essence of womanhood and 'femininity'. In doing so we hope to demonstrate that mother culture is alive and well, embedded in contemporary perfume marketing campaigns, all of which pay homage to goddess culture, female archetypes and our pagan past, and all of which refer to a Celtic value system rather than an Anglo-Saxon one.

\section{MOTHER GODDESS CULTURE}

The mother goddess culture is well documented throughout Europe. Gimbutas (in Green, 1997) traces the cult from circa $7500 \mathrm{BC}$ to $3000 \mathrm{BC}$, spanning the late Mesolithic and earlier Neolithic periods. She notes that in these societies women had power and prominence. In France, depictions of a maternal goddess decorate cave walls and tombs of Petit-Morin (Green, 1996). Ancient Megalithic monuments, throughout Europe, were associated with fertility and sexual activity. In Co. Clare in Ireland, for instance, there are 65 monuments associated with the beds of Diarmid and Grainne during their year and a day elopement (Menafee, 1996). In the Paleolithic period, throughout Northern Europe, female figurines were buried in secret places (Hutton, 1991). These female figurines, often with exaggerated physical characteristics, have been perceived as evidence of the Earth Mother culture.

Throughout pre-Celtic Europe pagan values prevailed, a matricentred society that revered nature, the sanctity of the land, and the never-ending cycle of birth, life and death. These goddesses were often depicted with fruit, babies, loaves or trees, to represent their connection to life and growth (Green, 1997). The landscape embodied the sacred goddesses and they were an ever-present force in people's lives, in imagination, meditation and creative energies, and in terms of their awareness of the forces of life and death around them (Stewart, 1990).

The concept of a mother goddess has enjoyed something of a renaissance in the past 20 years, embraced by Second Age feminists, white witches, and New Age and neo-pagan aficionados, to name but a few. It has also been recently popularised by Dan Brown's bestseller, The Da Vinci Code. The mother goddess as a symbolic or archetypal image has power at two levels: as a historical reality, and/or as a metaphorical paradigm (Wood, 1996). The female archetypes that populate goddess culture thus operate at both a psychological and a cultural level; they are both psychological complexes and cultural realities (Pratt, 1994). The myth of the mother goddess and how this concept has been played out and adapted by humanity, illustrates the possibilities, complications and above all the fluidity of myths generally, and their interplay with changing situations. It is their flexibility that has given them longevity, adaptability, and has ensured their enduring fascination (Billington, in Billington and Green, 1996). Goddess culture is a paradigm that is compelling, both in terms of its qualities and in terms of its persistence and pervasiveness in different historical periods and cultural contexts (Wood, 1996).

The ambivalent tensions between the actual and the metaphorical characterise and indeed lie at the centre of goddess culture. Goddesses were all-encompassing, powerful forces embodying both good and evil, life and death, creativity and destruction, peace and war, animalism and spirituality. Such contradictions, whilst confusing to modernist sensibilities and propensities for polarisations and binary opposites, are welcomed in a postmodern world (Brown, 1995) and certainly were accepted without question in ancient societies. Goddesses were full of contradictions; they were all-encompassing deities that were 'formidable forces of energy which could only be controlled, if at all, by due respect and acknowledgement of their power' (Green, 1996, p. 7). Wood (1996) 
perhaps sums it up when she observes that goddess culture is located in an ancient 'Ur-culture'; it is, truly, the mother of all cultures.

\section{CELTICISM AND THE MOTHER GODDESS CULTURE}

Celtic culture embraced many of the feminine values of this earlier mother culture based on nature's cycles, adapting it to suit its own values, but without erasing its most fundamental element, the power of Mother Nature itself. In Celtic society the concept of a mother goddess was entirely consistent with its earlier, Neolithic predecessor, which was a sedentary, matrilineal community (Green, 1997). In this community the focus of all human endeavour was the land and natural forces. The Celts, for example, believed that every district was under the protection of a goddess (Hutton, 1991). The land itself was usually represented by a goddess, and the Celts upheld the sanctity of life and the land, both of which worked together in harmony (Stewart, 1990). This reverence towards nature and the land was entirely to be expected, given that the Celts were primarily a rural, farming culture (Green, 1997).

Whilst the identification of Celticism with mother goddess culture is questioned by some (see, e.g., Hutton, 1991), there can be little doubt that the Celts embraced many aspects of this earlier time and assimilated them into their belief system, particularly in relation to how they perceived women. Perhaps because of their matricentred past, the Celts held goddesses and their transcendent, feminine powers in high reverence (Stewart, 1990), and women in Celtic society occupied extremely powerful positions, witness Queen Mebh of Connacht in Ireland and the rule of Boudica of the Icem in Britain (Green, 1997).

According to Celtic belief, the main supernatural powers were indisputably female (Green, 1997). As a polytheistic belief system, the ancient Celts perceived the presence of spirits in all aspects of the natural world; every tree, river and mountain possessed a spirit. The sun was a life force, its invocation symbolising fertility and healing, light and heat. In Ireland, for example, sun deities were goddesses such as the eponymous Eriu (ibid.) and Macha (Condren, 1989). In Celtic mythology the natural and the supernatural are inseparable from one another. Indeed there is continuity and communication between these two realms, which ensures their 'organic unity' (Sjoesfedt, 1949, p.1). The concept of a goddess empowering a male mortal through sexual intercourse is a powerful, universal one that symbolised the goddess' blessing on the whole community (Pratt, 1994). In pre-Christian rites the king mated with the mother goddess, ensuring fertility for the land and its people in the year to come (Sjoestedt, 1949; Condren, 1989; Green, 1997). Irish mythology is ripe with references to kings embracing nature, often in the form of fearsome animals, to symbolise the union of humanity with the land and to ensure the welfare and prosperity of their kingdom. Cuchulainn, for example, was said to have kissed a dragon that then turned into a beautiful maiden (Condren, 1989, Stewart, 1990, Hutton, 1991).

In Ireland, the name Eire itself bears testimony to this heritage, indeed it is derived from the Goddess Eriu, one of Ireland's triple goddesses. In myth anyone wishing to enter Ireland had to revere the triple goddesses of Eriu, Banba and Fotla if they wished to prosper and be fruitful, and Ireland itself was known in ancient times as 'the island of Banda of the women' (Condren, 1989). Rivers were also identified with Ireland's goddess culture, as birth canals, confluences, and sources of life. The River Boyne, scene of an esteemed colleague's recent epiphany (Brown, 2004), was itself called after the Goddess Boand, and the ancient symbol of the Triple Spiral, which decorates Newgrange in the Boyne Valley, is none other than the pagan 'cycle of eternal return', birth, life and death; represented in the triplicity of the Celtic goddesses: a sister or virgin, a nature goddess or lover and a Dark Mother; maiden, mother and crone (Condren, 1989; Stewart, 1990). 


\section{IRISH CELTIC GODDESSES}

A significant category of Celtic goddesses was the maiden goddesses. The maiden goddesses were associated with beauty, sorrow and joy. Often these maidens drew the hero into the Otherworld and set him a task to test his manhood and bravery. To fail in these challenges was to fail as a servant of his people. The Goddess Etain is an exemplar of a maiden archetype. She is parted from her immortal husband, Madhir, and marries the king of Ireland. Eventually her immortal husband finds her and plays chess to try and win her back. He succeeds, and despite the king's efforts to prevent her leaving, Etain and Midhir turn into swans and rise through the roof. These maiden goddesses were young and often golden-haired. The Goddess of Erin had white skin and yellow glittering hair to below her knees (Stewart, 1990).

An equally important category of Celtic goddess culture was the tutelary goddesses (associated with nature, animals and fertility). Brigit, a collective, multi-functional goddess, was identified with the sun and moon, vultures, serpents, cows, sheep, sacred fires, milk, ale and childbirth. Interestingly, her association with fire, representing culture, inspiration and smith craft, meant that she was a patroness of poets. In annual celebrations the chief poet in the village would lead a procession in honour of Brigit and carry a golden branch with tinkling bells to honour her. As such, she represented both nature and culture. The ancient Celts did not dichotomise these two forces in their lives; witness the merging of fertility and death on the battlefield, which will be discussed in due course. To this day Brigit is honoured in parts of Scotland and Ireland, with perpetual fires kept burning in her honour (Stewart, 1990).

The Epona, or horse goddess, was a major Celtic goddess, associated with energy, power and fertility (ibid.). Macha, the Ulster Epona, was a complex goddess, who is symbolic of prophecy, sovereignty, fertility, and closely bound up with the fortunes of the land itself. Sometimes referred to as the sun goddess (Condren, 1989), she is also noteworthy for embodying two key categories of goddesses in Irish mythology: she was both a tutelary goddess and a warrior goddess (Sjoestedt, 1949). Macha is credited with putting a curse on the sons of Ulster and for presiding over the grim crop reaped on the battlefield.

Finally, there was a significant category of Irish Celtic goddesses often referred to as the warrior goddesses. Three Irish goddesses, the Morrigan, Badhbh and Nemhain, were attendants at battle, exulting in slaughter and sponsors of war (Hutton, 1991). The Morrigan, meaning 'phantom queen', was a goddess of battle, death and sexuality. Nemhain means 'frenzy' and Badhbh means 'crow' or 'raven' (Stewart, 1990). Known as the battle furies, these three goddesses were all tripleformed, had prophetic, psychological powers that could unnerve the enemy, and all were associated with sexuality and death (Green, 1997). The Morrigan was a red-haired goddess who was feared above all else, and she signals the death of Cuchulain, the mythic hero of ancient Irish legend. The warrior goddesses, like other Celtic goddesses, had the ability to change shape, and indeed female shape-shifters are recurring myths in ancient, pre-Christian culture throughout Europe (Raudvere, 1996).

The concept of mother goddesses as bountiful benefactors bringing prosperity and fertility to its people was to some extent debased by the advent of the warrior goddesses. They became terrifying female deities of war, crows on the battlefield (Hutton, 1991). To gender as female the destructive and inhuman powers of slaughter is a remarkable juxtaposition in some respects, but the warrior goddesses did not engage in battle; they merely presided over the natural event, in supernatural form (Sjoestedt, 1949). Stewart (1990) writes that the conflation of the Celtic goddesses fertility powers with those of war represent the fusion of sexuality and death, the openers and closers of the Celtic way of life, the givers and takers. Green (1997) argues that the 
mother goddesses' identification with warfare may have been as a result of the need to defend territory under attack. Sjoestedt (1949) suggests that this association of the battlefield with birth reflects the need to honour the mother goddess at times of danger or peril, when life and death hung in the balance.

According to Condren (1989), goddess mythology was replaced by a patriarchal mythology; and the world of nature and mothers was replaced by the world of culture and men. Fertility itself was redefined; men gave birth to the cultural life of the people through battle and death, and the male word triumphed over the female womb. This transformation was complete when the pre-Christian Triple Goddess of Eriu, Banda and Fotla was replaced by the Christian Holy Trinity of Father, Son and Holy Ghost, and the Mother Goddess was replaced by the Virgin Saint. The concept of a unified, all-encompassing mother goddess had been lost. Christianity is attributed with splitting the concept of a holistic goddess into polarised images of good and bad goddesses, a process, Pratt (1994) argues, that was essentially an androcentric one.

To summarise, the feminine principle was embodied in goddess archetypes in Celtic culture, which themselves drew on an earlier goddess culture. In holistic terms, the main elements of the goddess culture were the identification of women with nature and the land; life and death; carnality and animalism; sexual drive and fertility; spirituality, ethereality and supernatural forces; power and energy; and creativity and culture. These key elements can be conceptualized as multiple layers that are laid down upon the goddess core of Celtic culture, and additional layers were added by the advent of Christianity, which dichotomized a single goddess principle into two polarized opposites, the saintly virgin and the evil temptress.

In Irish Celtic mythology the key characteristics of goddess culture are found in varying degrees in the four primary goddesses previously mentioned: Etain, the maiden goddess, associated with beauty, sorrow, joy and innocence; Brigit, associated with fire, creativity, culture and nature; Macha, associated with energy, power, fertility and nature; and the Morrigan, associated with sexuality, battle, death, and the other world.

In the following analysis, we will argue that goddess culture and by extension, Celtic culture, are invoked in a product category whose raison d'etre is to capture the essence, or rather 'essences' of womanhood. The perfume industry delights in offering consumers female archetypes that symbolically represent the essence of their scents. Like the mythology on female archetypes, it also illustrates a process which lays down multiple layers and is thus particularly apposite for our purposes. Firstly, because the perfume industry attempts to capture the essence of particular archetypes of womanhood, designing and marketing products that appeal to female consumers' aspirations to signify their ideal 'femininity' to others, and to male consumers who traditionally buy perfume as a gift for women. Secondly, because like goddess culture, Celtic culture and Christianity, which represent layer upon layer of meaning and association built up over time, the lexicon of perfumery is also multi-layered, complex and at times contradictory. It is a lexicon that refers to distilling extracts and elixirs; to top notes, heart notes and base notes; and to the processes of enfleurage, extraction, absolute essence and maturation. In its use of female archetypes, the perfume industry offers marketing narratives that mirror the depth and complexity of the essences of the female goddesses it attempts to embody and capture in a bottle, and the secrets, promises and fantasies offered by its fragrances.

We now turn to our four Irish Celtic goddesses, Etain, Brigit, Macha and the Morrigan, for our interpretation of several contemporary advertising campaigns for perfume, in which these ancient archetypes of goddess culture are celebrated. 


\section{ETAIN: 'BEYOND PARADISE'}

The beauty, joy, sorrow and innocence of the maiden goddess archetype, Etain, is visible in the new advertising campaign for 'Beyond Paradise', which shows a beautiful young woman in a natural, indeed supernatural setting. Estee Lauder's, 'new fantasy in fragrance', represents a fair young woman walking along a magical, flower-strewn, butterfly-filled, rainbow-coloured, ethereal highway, recalling the youthful, childlike innocence of Dorothy in the Wizard of the $\mathrm{Oz}$. The ad features the Madonna song 'Love Profusion' from her American Life album: 'You make me feel, you make me shine'. The fragrance, described as 'dewy floral' and 'a floral fantasy', is a rainbow-coloured, iridescent raindrop, or teardrop, which adds a certain romanticism to the product, hinting as it does at emotional excess and its potential for sorrow. The merchandising for the brand displays the range of products against a pure white backdrop, heightening the effect of innocence and purity (<http://www.esteelauder.com>). The ethereal image of womanhood, which shows a woman surrounded by nature but also draws on strong supernatural overtones, is entirely consistent with goddess culture archetypes. Interestingly, in its association with Madonna, an iconic figure in contemporary popular culture who is now in her late-40s, it suggests to female consumers that 'Beyond Paradise' is indeed a youthful fragrance that may hold the secret of eternal youth to those who wear it. To juxtapose innocence with Madonna is to reconcile purity with sin, and negate the traditional binary thinking that surrounds femininity, particularly in the virgin/whore dichotomy. In this blending of paradoxical associations to target contemporary womanhood, this advertisement is also a good example of what Thompson (2004) refers to as 'marketplace mythology'.

\section{ETAIN: 'TRUE STAR'}

Etain, the maiden goddess, is also represented in the newly launched 'True Star' fragrance from Tommy Hilfiger, which comprises beauty, joy, innocence and a touch of sadness too. The scent captures 'the energy, passion and glowing beauty' of the celebrated and beautiful young American singer Beyoncé. Filmed in black and white, the TV advert shows Beyoncé in a reclined position, gazing at the viewer and singing, a capella, the song 'I'm Wishing on a Star': 'To follow where you are/I'm wishing on a dream/to follow what it means/And I'm wishing on a rainbow that I see'. Once again the fantasy appeal, the pot of gold at the end of a rainbow, is magically evoked in the fragrance narrative, but the black-and-white photography and the sentiments expressed in the song suggest wistful longing and hint at an underlying sadness. The perfume is inspired by Beyoncé's celebrity persona, but it also conveys 'the essence of her more personal, private side'. Tommy Hilfiger wanted to capture her essence: 'Independent, sexy, and true to herself, but her warmth and vulnerability also come through. That's a potent combination, whether you're talking about a music icon or marketing a fragrance' (<http://www.tommy.com>). This description reveals how these combinations of qualities are contrasted with one another. Can a woman be sexy but warm, independent but vulnerable? It is the woman-child archetype that is being conjured, one so poignantly embodied in another iconic woman of our time, Marilyn Monroe, and one that continues to appeal in our culture. Only the maiden goddess of Celtic mythology can reconcile this contradiction in terms of their simultaneous innocence and sexual appeal. In terms of notes, the scent reflects these inherent contradictions in its combination of florals with notes of 'toasted grain', all designed to capture Beyoncé in a bottle. 


\section{BRIGIT: 'J'ADORE’}

The characteristics of Brigit, fire, creativity, culture and nature, are encapsulated in the current advertising campaign for 'J'Adore', which features the beautiful Oscar-winning actress Charlize Theron reclining on a bed of gold and draped in gold satin (see Fig. 1). The set is luminous; evoking golden cornfields, sunlight and warmth, and her stance is one of passive and pleasurable acceptance of nature's bounty. The advertisement is a homage to gold, which not only suggests fire, light and warmth, but also hints at its malleability, a precious metal that can be shaped and moulded to ones heart's desire. Her eyes are closed and she presses the magical vial-like bottle of 'J'Adore' to her breast in a seemingly ecstatic manner. This is confirmed at the end of the ad when she opens her eyes, looks at the viewer and murmurs, 'J'Adore'. The perfume claims to be the expression of 'ultimate femininity'. It is described as 'a fragrant, golden icon, beckoning you to the ultimate emotion that will make you whisper "J'Adore". Elsewhere it is described as 'a new expression of emotion'. Words such as 'grace' and 'harmony' are used to convey its essence, and to reinforce its status as a magical elixir that can reveal the goddess in us. The Brigit archetype is one that is associated with life, light and poetry; in the 'J'Adore' advertisement, she is iconic and serene. The 'grace' referred to in the ad copy reminds us too of Brigit's later status as a Christian saint, in terms of both her beauty and her accomplishments as an actress. The perfume is a 'jewellike, gold-dusted treasure' which when opened will reveal the goddess in those who wear it.

\section{BRIGIT: 'CHANEL NO. 5'}

The essential characteristics of the Celtic goddess Brigit is also evoked in the current advertising campaign for 'Chanel No. 5'. For many women this is the ultimate fragrance, a 'timeless classic' that is probably the best-known perfume in the world. Chanel's current TV advertising campaign features the celebrated Australian actress Nicole Kidman, widely regarded as one of the most elegant and graceful actresses on the Hollywood 'A' list (see Fig. 2). It is no surprise, therefore, that Kidman embodies the essence of 'Chanel No. 5', a fragrance that describes itself as 'entrancing and elegant'. After all, Nicole Kidman sets 'a unique standard of elegance'. This scent conjures Brigit's association

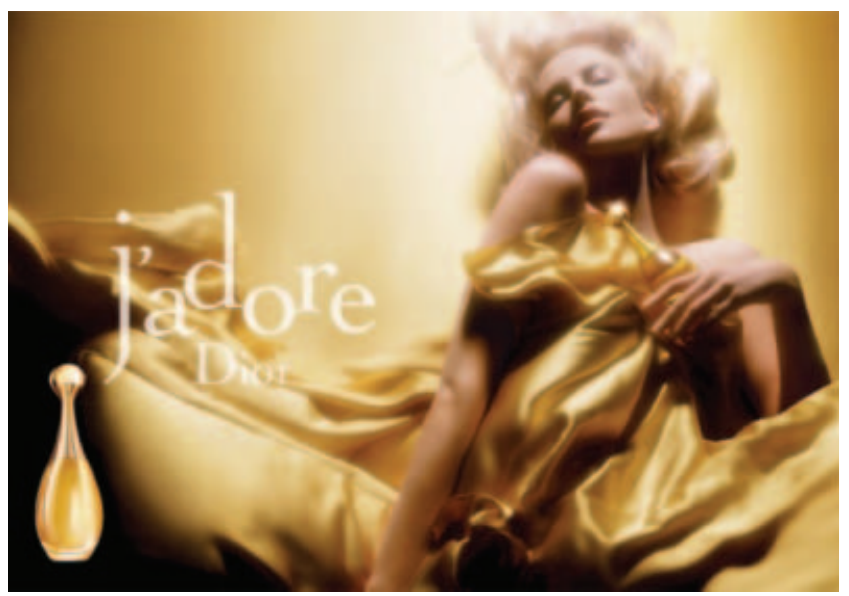

Figure I. Charlize Theron reclining on a bed of gold. Reproduced by kind permission of Parfums Christian Dior (UK) Ltd. 


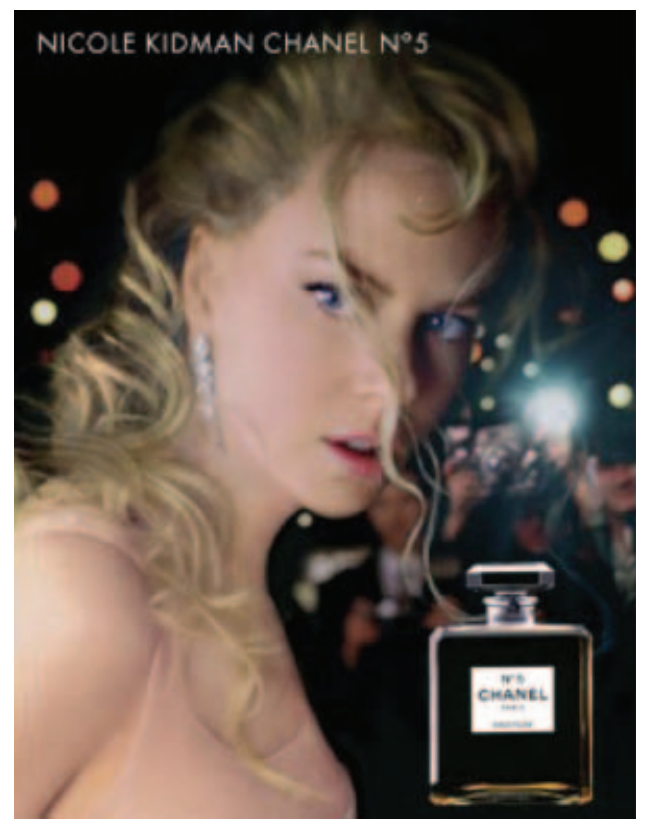

\section{Figure 2. Kidman, as the essence of Chanel No.5. Reproduced by kind permission of} Chanel (UK).

with creativity, culture and the arts. It marries Brigit's sensual associations with the cultural capital she also embodies, a true marriage of nature and culture, not unlike the actress chosen to symbolise its essence: a beautiful woman who is also an actress of the highest calibre, who has endured a marital break-up and has risen victoriously and with dignity above life's vicissitudes, with style and grace, to become one of the most acclaimed actresses of her generation.

\section{MACHA: 'TOUCH OF PINK'}

The energy, power and fertility of Macha are celebrated in Lacoste's new fragrance, 'Touch of Pink', which features a young, slim, blonde-haired and beautiful woman in a short pink dress. The perfume is for 'women with a real zest for life, who are genuine and spontaneous. An intriguing, fresh, fruity, floral fragrance'. The advertisement, which stars a young Danish singer who they regard as representing the essence of the scent, is shown in a cityscape. She is slim, light, coltish in her movements, and seems to dance along the street, gazing heavenwards, chasing a kite in the sky, whose ribbon evades her grasp, her long, golden hair dazzling against the sunlight and the reflection of the glass in the buildings around her. Her active movement and the significance of the sunlight in the advertisement recall the Epona (horse goddess) of Celtic mythology whose element is the sun. The narrative for the fragrance reads, 'Everyday is filled with moments of pleasure and delight. "Touch of Pink" is the spirit of feminine vitality that brings them to life' (<http://www.lacostepink.com>). The advertisement focuses on femininity as both energetic and joyous and in so doing evokes the essence of the Epona, in its homage to sunlight and vitality. The use of a female singer also reinforces the blending of nature and culture that is associated with goddess culture generally. 


\section{MACHA: 'HUGO DEEP RED'}

Hugo's 'Deep Red' TV ad campaign shows the Epona in a different light. The touch of pink is intensified to become a deep red, which, we argue, signifies the transformation of feminine vitality, fertility and power into its dark, predatory aspects. The ad indirectly recalls the ambivalence at the heart of Macha, the Ulster Epona, who came to be associated with the battlefield and her curse on the sons of Ulster. The ad features a dark, predatory and sexually demanding young woman bending a hapless male victim to her will. Dressed in a black satin mini dress, her stance is dominant, as she prises open the blinds in their bedroom, awakening him with the shaft of light, preparing to 'interrogate' him. The strap line is, 'Always wait for him to make the first move? Your fragrance, your rules'. This is a female archetype that is an ancient one in Goddess and Celtic culture, her stance mirroring that of the pagan goddess astride two rivers who forces the Celtic king to copulate with her. The concept of a woman in a sexually dominating role was not a controversial one in pagan times. The female protagonist in the 'Deep Red' television advertisement, a celebrated model in her own right, embodies the qualities of the Epona in her energy, power and fertility, and the packaging is designed to embody 'selfconfident, playful seduction'. The bottle itself is described as being inspired by the shape of highheeled shoes and a champagne glass. She is at 'the border between self-confidence and dominance'. Above all, she is 'free to express her passion and sensuality' and 'she's up for everything, like "Deep Red"” (<http://www/hugofragrances.com>). Clearly she is positioned as more sinner than saint. 'Deep Red' is consistent with the influence of Christianity on the Goddess Macha, which injected sin into this mythic narrative, so that the archetype became more associated with devilry, dark forces and death on the battlefield rather than joyous sexuality, fertility and prosperity for all. And whilst the 'Deep Red' advertisement addresses the sexual energy and fertility associated with the Epona archetype, it also hints at the darker forces of goddess culture. Its underlying 'note' is an ominous one, hinting at death and destruction, embodied in the Morrigan.

\section{THE MORRIGAN: 'PURE POISON'}

Surprisingly, perhaps, there is a place for a highly dangerous and potentially lethal female archetype in the lexicon of perfumery. As previously mentioned, The Morrigan was a fierce female warrior goddess in Celtic mythology, a force of death and destruction, who presided over the battlefield. She was associated with sexuality, battle, death and the other world. In psychological terms, this terrifying image of female power is often described, in Freudian or Jungian terms, as a castrator of men, a 'vagina dentata' or 'terrible mother' to be overcome (Pratt, 1994). As previously discussed, the warrior goddesses were frequently identified with powerful sexual drives, which were somehow combined with death and destruction, a juxtaposition explained by Sjoestedt (1949), as symbolic of the cycle of life and death, represented on the battlefield and on the bed of childbirth. Although the Morrigan is red-haired in Irish mythology, this archetype is more typically associated with the dark lady, Hollywood vamp or the gothic temptress in contemporary cultural texts; the raven-haired, red-lipped seductress, the sinner who presides over man's downfall. The Morrigan can be found in 'Pure Poison'.

Dior's 'Pure Poison' is a 'universe' that 'celebrates seduction' and the darker forces associated with goddess culture. This is the archetype of woman as a formidable, indomitable force of nature that cannot be resisted. And interestingly, the positioning of the brand assumes that its target market want to be a seductive, irresistible force. It is 'a secret potion', enigmatic, 'dangerously 


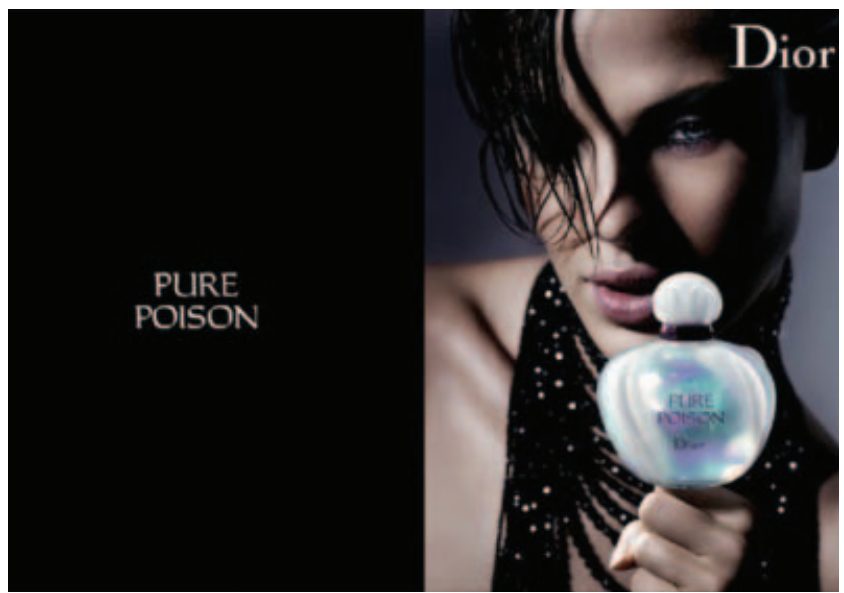

\section{Figure 3. 'Pure Poison'. Reproduced by kind permission of Parfums Christian Dior (UK)} Ltd.

irresistible' and hints at dark forces in its ambivalent qualities: it is 'clear yet mysterious', openhearted yet enigmatic, juxtaposing the two binary oppositions that are the hallmark of the Celtic narrative (<http://www.dior.com>). The TV ad shows a woman with a black panther, presumably her alter ego. She is darkly lit, and sultry eyed, with tendrils of damp hair partially obscuring one side of her face, and she is dressed in a black, sparkling dress. A bottle of 'Pure Poison' rests on the knuckles of a hand she clenches in a fist in front of her, challenging the viewer, and she gazes at the camera, her expression rapt and intense, yet also suggestive of a drugged state, her lips apart, her eyelids dark and heavy. Her sleek animal companion mirrors her slightly ambiguous, defiant and hypnotic gaze, and we recall the shape-shifting qualities of the Morrigan, and other ancient goddesses. At any moment she will become a panther and pounce mercilessly on her prey.

\section{DISCUSSION}

The above discussion has shown how archetypes of womanhood in advertising draw on Celtic archetypes of womanhood, which themselves draw on pagan archetypes. These ancient archetypes in turn merge with contemporary iconic figures such as Madonna, revealing myths to be complex narrative structures that contain many layers of cultural meanings. In the analysis above, we have shown how the Celtic goddess narratives are a blending of various tensions and dilemmas that are relevant to perceptions of contemporary femininity. Hence, we suggest, the appeal of these narratives that acknowledge women to be at once pure and poisonous, seduced and seducer.

Given the current emphasis on myth making in marketing (Holt, 2004; Vincent, 2002; Thompson, 2004), it is timely for marketers to understand the deep cultural meanings that inhere in marketplace phenomena, and how these draw from rich, often unconscious sources in the human psyche. McCracken (1988) has highlighted how meanings are continually transferring between the culturally constituted world (where advertising plays a key role), the world of goods, and the individual consumer. Rather than a one-way movement from producers to consumers, this meaning transfer is a continual dialectical interplay between producers and consumers (Holt, 2004). The use of mythic archetypes, we suggest, illustrates this dialectical interplay, as marketers 
draw from the collective cultural unconscious-in this case, we argue, the Celtic goddess narratives - to present and re-present narratives that once again resonate with contemporary consumers. This creative process links integral to the development of marketing strategy because, to quote Holt (ibid., p. 92):

To build iconic brands, managers must not only target the appropriate contradiction in society, but also must develop a compelling myth to address this contradiction.

\section{REFERENCES}

Billington, S. and Green, M. (eds) (1996) The Concept of the Goddess, London: Routledge.

Brown, S. (1995) Postmodern Marketing, London: Routledge.

Brown, S. (2006) Tiocfaidh ār lā: introduction to the special issue. Journal of Strategic Marketing 14(1).

Condren, M. (1989) The Serpent and the Goddess, Women, Religion, and Power in Celtic Ireland, New York: Harper Collins Publishers.

Green, M.J. (1996) The Celtic World, London: Routledge.

Green, M.J. (1997) The Gods of the Celts, Bridgend: Sutton Publishing.

Hirschman, E.C. (2000) Heroes, Monster, and Messiahs: Movies and Television Shows as the Mythology of American Culture, Kansas City: Andrews McMeel Publishing.

Holt, D. (2004) How Brands Become Icons: The Principles of Cultural Branding, Boston, Massachusetts: Harvard Business Press.

Hutton, R. (1991) The Pagan Religions of the British Isles: Their Nature and Their Legacy, Oxford: Blackwell. McCracken, G. (1988) Culture and Consumption, Bloomington: Indiana University Press.

Menafee, S.P. (1996) Meg and her daughters: some traces of goddess-beliefs in megalithic folklore?. In: S. Billington and M. Green (eds) The Concept of the Goddess, London: Routledge, 78-90.

Paglia, C. (1992) Sexual Personae: Art and Decadence from Nefertiti to Emily Dickinson, Middlesex: Penguin Books.

Pratt, A. (1994) Dancing with Goddesses: Archetypes, Poetry, and Empowerment, Bloomington and Indianapolis: Indiana University Press.

Raudvere, C. (1996) Now you see her, now you don't: some notes on the conception of female shapeshifters in Scandinavian tradition. In: S. Billington and M. Green (eds) The Concept of the Goddess, London: Routledge, 41-55.

Sjoestedt, M.L. (1949) Gods and Heroes of the Celts (transl. Myles Dillon), London: Methuen \& Co Ltd.

Stewart, R.J. (1990) Celtic Gods, Celtic Goddesses, London: Blandford.

Thompson, C.J. (2004) Marketplace mythology and discourses of power. Journal of Consumer Research 31(1), June, 162-80.

Vincent, L. (2002) Legendary Brands: Unleashing the Power of Storytelling to Create a Winning Market Strategy, Chicago, Illnois: Dearborn Trade Books.

Wood, J. (1996) The concept of the goddess. In: S. Billington and M. Green (eds) The Concept of the Goddess, London: Routledge, 8-25. 